\title{
Synthesis, Hammett spectral correlations and antimicrobial activities of (E)-1-benzylidene-2-(4-chlorophenyl)hydrazines
}

\author{
M. Rajarajan ${ }^{a}$, R. Vijayakumar ${ }^{a}$, R. Senbagam ${ }^{a}$, S. Balaji ${ }^{a}$, V. Manikandan ${ }^{a}$, \\ G. Vanangamudi and $G$. Thirunarayanan ${ }^{*, b}$
}

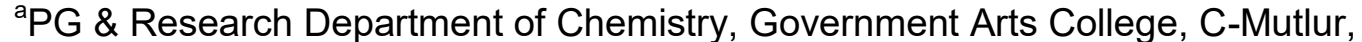 Chidambaram - 608 102, India.

bepartment of Chemistry, Annamalai University, Annamalainagar-608 002, India.

*E-mail: drgtnarayanan@gmail.com

\begin{abstract}
Keywords: Synthesis, Hydrazones, Acetic acid, 4-chlorophenylhydrazine, Spectral correlation, 4-chlorophenylhydrazone and Antimicrobial activities
\end{abstract}

\begin{abstract}
In the present study, a series of nine number of (E)-1-benzylidene-2-(4chlorophenyl)hydrazine compounds have been synthesized by condensation reaction of meta and para substituted benzaldehydes with 4-chlorophenylhydrazine using acetic acid catalyst. They are characterized by their physical constants, UV (200-450 nm), Infra-Red $\left(\mathrm{KBr}, 4000-400 \mathrm{~cm}^{-1}\right)$ and NMR $\left({ }^{1} \mathrm{H}\right.$ and $\left.{ }^{13} \mathrm{C}\right)$ spectral data. The observed UV, IR and NMR spectral data have been correlated with Hammett substituent constants and Swain-Lupton's $F$ and $R$ parameters using single and multi-linear regression analysis. From the results of statistical analysis the effects of substituents on the spectral data have been discussed. The antimicrobial activities of all the synthesized $(E)-1-$ benzylidene-2-(4-chlorophenyl)hydrazine compounds have been studied using Bauer-Kirby method.
\end{abstract}

\section{Introduction}

Hydrazones are a class of organic compounds in the Schiff base family [1]. They are constitute a versatile compound of organic class having the basic structure $\mathrm{R}_{1} \mathrm{R}_{2} \mathrm{C}=\mathrm{NNR}_{3} \mathrm{R}_{4}$ [2-3]. The two nitrogen atoms of hydrazone are nucleophilic but the amino type nitrogen is more reactive, whereas the carbon atom possesses both characters, that is, nucleophilic and electrophilic. The active centres of hydrazine, that is, carbon and nitrogen, are mainly responsible for the physical and chemical properties of the hydrazones and due to the reactivity toward electrophiles and nucleophiles, hydrazones are used for the synthesis of organic compound such as heterocyclic compounds [4-5] .

The general method for the synthesis of the hydrazones is the reaction of hydrazine with carbonyl compounds such as aldehydes or ketones in solvents like ethanol, methanol, butanol [6-8], and so forth. Hydrazone containing azomethine $-\mathrm{NHN}=\mathrm{CH}$ protons constitute an important class of compounds for new drug development [9]. Many researchers have been synthesized these compounds as target structures and evaluated their antimicrobial [10], antitubercular [11], anticonvulsant [12], analgesic [13], anti-inflammatory [14], antiplatelet [15], anticancer [16], antiviral [17], antitumoral [18], antimalarial [19], antioxidant [20], analgesic [21], ntiprotozoal [22], antiparasitic [23], cardioprotective [24], antidepressant [25] and anti-HIV [26]. They are also used to couple with certain drugs and the bonds based on hydrazones are stable at the neutral PH [27]. Hydrazones have been investigated as potential charge-transport materials for organic photoconductors [28] and nonlinear optical polymers [29]. From through literature survey it is observed that there is no report on the effect of substituents QSAR or QPR study with these (E)-1-benzylidene-2-(4-chlorophenyl)hydrazines, in the past. Therefore the authors take effort to synthesis some substituted (E)-1-benzylidene-2-(4-chlorophenyl)hydrazines and study the correlation analysis with their UV, IR and NMR spectral data and study their antimicrobial activities by using disc diffusion technique. 


\section{Experimental Section}

\subsection{Materials and Methods}

All the chemicals used in the present investigation have been purchased from Sigma-Aldrich and E-Merck chemical companies. Melting points of all the substituted (E)-1-benzylidene-2-(4-chlorophenyl)hydrazine compounds have been determined in open glass capillaries on a Mettler FP51 melting point apparatus and are uncorrected. The electronic spectra of all the synthesized (E)-1-benzylidene-2-(4-chlorophenyl)hydrazines have been recorded on a SHIMADZU-1650 SPECTROMETER $\left(\lambda_{\max }, \mathrm{nm}\right)$ in spectral grade methanol. SHIMADZU-2010 FT-IR SPECTROMETER has been utilized for recording FT-IR ( $\mathrm{KBr}$ pellet, $4000-400 \mathrm{~cm}^{-1}$ ) spectra. The ${ }^{1} \mathrm{H}$ NMR and ${ }^{13} \mathrm{C}$ NMR spectra of all the synthesized $(E)$-1-benzylidene-2-(4chlorophenyl)hydrazines compounds have been recorded with BRUKER AV400 NMR spectrometer using $\mathrm{CDCl}_{3}$ as a solvent and TMS as an internal standard.

\subsection{Synthesis of substituted (E)-1-benzylidene-2-(4-chlorophenyl)hydrazines}

A mixture of equimolar quantities of substituted benzaldehydes $(0.01 \mathrm{~mol})$ and 4-chlorophenylhydrazine $(0.01 \mathrm{~mol})$, acetic acid $(0.5 \mathrm{~mL})$ and $20 \mathrm{~mL}$ of ethanol were taken in $100 \mathrm{~mL}$ round bottom flask the mixture was refluxed [30] for 3 hours as shown in Scheme-1. The completion of the reaction was monitored by TLC continuously. The resultant mixture was cooled at room temperature. Then the precipitate obtained, was filtered at the filter pump and washed several times with cold water. This crude product was recrystallized from ethanol and their melting points have been noted. All the synthesized $(E)$-1-benzylidene-2-(4-chlorophenyl)hydrazines have been identified by their physical constants, UV, IR and NMR spectral data as shown in Table 1. The spectral data of all of substituted (E)-1-benzylidene-2-(4-chlorophenyl)hydrazines have been correlated with Hammett substituent constants and $F$ and $R$ parameter and are shown in Table 2.

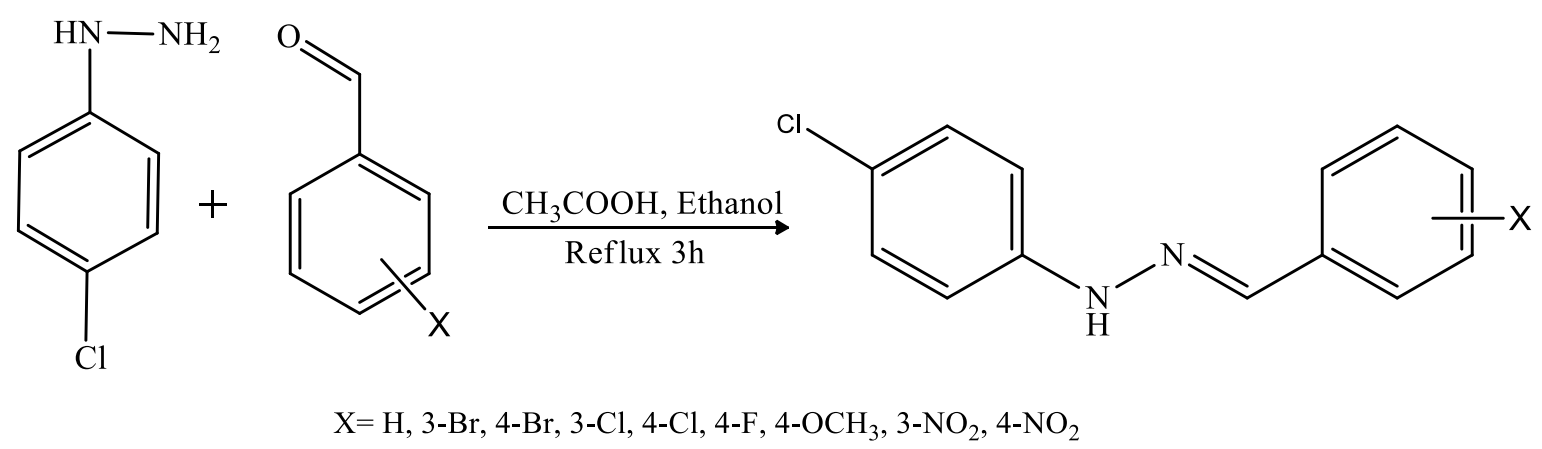

Scheme 1. Synthesis of substituted (E)-1-benzylidene-2-(4-chlorophenyl)hydrazines. 
Table1. The physical constants, UV, IR and NMR data of $(E)$-1-benzylidene-2-(4chlorophenyl)hydrazines

\begin{tabular}{|c|c|c|c|c|c|c|c|c|c|}
\hline Entry & $\mathrm{X}$ & m.p $\left({ }^{\circ} \mathrm{C}\right)$ & M. F & M. W & $\begin{array}{l}\text { Yield } \\
(\%)\end{array}$ & $\begin{array}{l}\lambda_{\max } \\
(\mathrm{nm})\end{array}$ & $\begin{array}{l}v \mathrm{C}=\mathrm{N} \\
\left(\mathrm{cm}^{-1}\right)\end{array}$ & $\begin{array}{c}\delta^{1} \mathrm{H} \\
\mathrm{CH}=\mathrm{N} \\
(\mathrm{ppm})\end{array}$ & $\begin{array}{c}\delta^{13} \mathrm{C} \\
\mathrm{C}=\mathrm{N} \\
(\mathrm{ppm})\end{array}$ \\
\hline 1 & $\mathrm{H}$ & $\begin{array}{c}103-104 \\
{[103-105][31]}\end{array}$ & $\mathrm{C}_{13} \mathrm{H}_{11} \mathrm{~N}_{2} \mathrm{Cl}$ & 230 & 80 & 348 & 1583.56 & 8.318 & 143.31 \\
\hline 2 & $3-\mathrm{Br}$ & $80-81$ & $\mathrm{C}_{13} \mathrm{H}_{10} \mathrm{~N}_{2} \mathrm{BrCl}$ & 309 & 82 & 354.5 & 1591.27 & 8.105 & 150.85 \\
\hline 3 & $4-\mathrm{Br}$ & $108-109$ & $\mathrm{C}_{13} \mathrm{H}_{10} \mathrm{~N}_{2} \mathrm{BrCl}$ & 309 & 84 & 355.5 & 1587.42 & 7.78 & 142.99 \\
\hline 4 & $3-\mathrm{Cl}$ & $79-80$ & $\mathrm{C}_{13} \mathrm{H}_{10} \mathrm{~N}_{2} \mathrm{Cl}_{2}$ & 265 & 86 & 354 & 1587.42 & 7.923 & 150.88 \\
\hline 5 & $4-\mathrm{Cl}$ & $101-102[32]$ & $\mathrm{C}_{13} \mathrm{H}_{10} \mathrm{~N}_{2} \mathrm{Cl}_{2}$ & 265 & 83 & 348 & 1587.42 & 8.386 & 151.1 \\
\hline 6 & $4-F$ & 104-105 & $\mathrm{C}_{13} \mathrm{H}_{10} \mathrm{~N}_{2} \mathrm{FCl}$ & 248 & 86 & 347.5 & 1595.13 & 7.634 & 144.74 \\
\hline 7 & $4-\mathrm{OCH}_{3}$ & $151-152$ & $\mathrm{C}_{14} \mathrm{H}_{13} \mathrm{~N}_{2} \mathrm{OCl}$ & 260 & 85 & 350 & 1600.92 & 7.847 & 143.63 \\
\hline 8 & $3-\mathrm{NO}_{2}$ & $123-124$ & $\mathrm{C}_{13} \mathrm{H}_{10} \mathrm{~N}_{3} \mathrm{O}_{2} \mathrm{Cl}$ & 275 & 87 & 350.5 & 1593.2 & 7.686 & 147.93 \\
\hline 9 & $4-\mathrm{NO}_{2}$ & $153-154$ & $\mathrm{C}_{13} \mathrm{H}_{10} \mathrm{~N}_{3} \mathrm{O}_{2} \mathrm{Cl}$ & 275 & 81 & 340.5 & 1575.84 & 7.661 & 147.19 \\
\hline
\end{tabular}


Table 2. Results of statistical analysis of UV $\lambda_{\max }(\mathrm{nm}), v_{\mathrm{C}=\mathrm{N}}\left(\mathrm{cm}^{-1}\right) \mathrm{IR}, \mathrm{NMR} \delta^{1} \mathrm{H}(\mathrm{ppm}) \mathrm{CH}=\mathrm{N}$ and $\delta^{13} \mathrm{C}(\mathrm{ppm}) \mathrm{C}=\mathrm{N}$ data of substituted $(E)$-1-benzylidene-2-(4-chlorophenyl)hydrazines with Hammett substituent constants $\sigma, \sigma^{+}, \sigma_{\mathrm{I}}, \sigma_{\mathrm{R}}$ and $F$ and $R$ parameters.

\begin{tabular}{|c|c|c|c|c|c|c|c|}
\hline Frequency & Constants & $\mathrm{r}$ & I & $\rho$ & $\mathrm{s}$ & $\mathrm{n}$ & Correlated derivatives \\
\hline \multirow{6}{*}{$\lambda_{\max }(\mathrm{nm})$} & $\sigma$ & 0.862 & 350.67 & -3.01 & 4.81 & 9 & $\mathrm{H}, 3-\mathrm{Br}, 4-\mathrm{Br}, 3-\mathrm{Cl}, 4-\mathrm{Cl}, 4-\mathrm{F}, 4-\mathrm{OCH}_{3}, 3-\mathrm{NO}_{2}, 4-\mathrm{NO}_{2}$ \\
\hline & $\sigma^{+}$ & 0.802 & 349.97 & -0.65 & 4.93 & 9 & $\mathrm{H}, 3-\mathrm{Br}, 4-\mathrm{Br}, 3-\mathrm{Cl}, 4-\mathrm{Cl}, 4-\mathrm{F}, 4-\mathrm{OCH}_{3}, 3-\mathrm{NO}_{2}, 4-\mathrm{NO}_{2}$ \\
\hline & $\sigma_{1}$ & 0.816 & 351.46 & -3.75 & 4.87 & 9 & $\mathrm{H}, 3-\mathrm{Br}, 4-\mathrm{Br}, 3-\mathrm{Cl}, 4-\mathrm{Cl}, 4-\mathrm{F}, 4-\mathrm{OCH}_{3}, 3-\mathrm{NO}_{2}, 4-\mathrm{NO}_{2}$ \\
\hline & $\sigma_{\mathrm{R}}$ & 0.827 & 349.02 & -5.76 & 4.75 & 9 & $\mathrm{H}, 3-\mathrm{Br}, 4-\mathrm{Br}, 3-\mathrm{Cl}, 4-\mathrm{Cl}, 4-\mathrm{F}, 4-\mathrm{OCH}_{3}, 3-\mathrm{NO}_{2}, 4-\mathrm{NO}_{2}$ \\
\hline & $F$ & 0.820 & 351.76 & -4.26 & 4.83 & 9 & $\mathrm{H}, 3-\mathrm{Br}, 4-\mathrm{Br}, 3-\mathrm{Cl}, 4-\mathrm{Cl}, 4-\mathrm{F}, 4-\mathrm{OCH}_{3}, 3-\mathrm{NO}_{2}, 4-\mathrm{NO}_{2}$ \\
\hline & $R$ & 0.826 & 348.98 & -4.63 & 4.76 & 9 & $\mathrm{H}, 3-\mathrm{Br}, 4-\mathrm{Br}, 3-\mathrm{Cl}, 4-\mathrm{Cl}, 4-\mathrm{F}, 4-\mathrm{OCH}_{3}, 3-\mathrm{NO}_{2}, 4-\mathrm{NO}_{2}$ \\
\hline \multirow[t]{6}{*}{$v \mathrm{C}=\mathrm{N}\left(\mathrm{cm}^{-1}\right)$} & $\sigma$ & 0.905 & 1592.44 & -11.87 & 6.341 & 7 & 3-Br, 4-Br, 3-Cl, 4-Cl, 4-F, 4- $\mathrm{OCH}_{3}, 4-\mathrm{NO}_{2}$ \\
\hline & $\sigma^{+}$ & 0.906 & 1591.28 & -9.74 & 5.83 & 7 & 3-Br, 4-Br, 3-Cl, 4-Cl, 4-F, 4- $\mathrm{OCH}_{3}, 4-\mathrm{NO}_{2}$ \\
\hline & $\sigma_{1}$ & 0.809 & 1590.58 & -3.34 & 7.64 & 9 & $\mathrm{H}, 3-\mathrm{Br}, 4-\mathrm{Br}, 3-\mathrm{Cl}, 4-\mathrm{Cl}, 4-\mathrm{F}, 4-\mathrm{OCH}_{3}, 3-\mathrm{NO}_{2}, 4-\mathrm{NO}_{2}$ \\
\hline & $\sigma_{\mathrm{R}}$ & 0.906 & 1585.98 & -22.48 & 5.57 & 8 & $\mathrm{H}, 3-\mathrm{Br}, 4-\mathrm{Br}, 3-\mathrm{Cl}, 4-\mathrm{Cl}, 4-\mathrm{F}, 4-\mathrm{OCH}_{3}, 4-\mathrm{NO}_{2}$ \\
\hline & $F$ & 0.804 & 1588.42 & -1.57 & 7.66 & 9 & $\mathrm{H}, 3-\mathrm{Br}, 4-\mathrm{Br}, 3-\mathrm{Cl}, 4-\mathrm{Cl}, 4-\mathrm{F}, 4-\mathrm{OCH}_{3}, 3-\mathrm{NO}_{2}, 4-\mathrm{NO}_{2}$ \\
\hline & $R$ & 0.907 & 1585.34 & 19.79 & 5.31 & 8 & $\mathrm{H}, 3-\mathrm{Br}, 4-\mathrm{Br}, 3-\mathrm{Cl}, 4-\mathrm{Cl}, 4-\mathrm{F}, 4-\mathrm{OCH}_{3}, 4-\mathrm{NO}_{2}$ \\
\hline \multirow[t]{6}{*}{$\delta \mathrm{CH}=\mathrm{N}(\mathrm{ppm})$} & $\sigma$ & 0.805 & 7.907 & 0.052 & 0.32 & 9 & $\mathrm{H}, 3-\mathrm{Br}, 4-\mathrm{Br}, 3-\mathrm{Cl}, 4-\mathrm{Cl}, 4-\mathrm{F}, 4-\mathrm{OCH}_{3}, 3-\mathrm{NO}_{2}, 4-\mathrm{NO}_{2}$ \\
\hline & $\sigma^{+}$ & 0.832 & 7.917 & 0.019 & 0.32 & 9 & $\mathrm{H}, 3-\mathrm{Br}, 4-\mathrm{Br}, 3-\mathrm{Cl}, 4-\mathrm{Cl}, 4-\mathrm{F}, 4-\mathrm{OCH}_{3}, 3-\mathrm{NO}_{2}, 4-\mathrm{NO}_{2}$ \\
\hline & $\sigma_{1}$ & 0.803 & 7.914 & -0.051 & 0.32 & 9 & $\mathrm{H}, 3-\mathrm{Br}, 4-\mathrm{Br}, 3-\mathrm{Cl}, 4-\mathrm{Cl}, 4-\mathrm{F}, 4-\mathrm{OCH}_{3}, 3-\mathrm{NO}_{2}, 4-\mathrm{NO}_{2}$ \\
\hline & $\sigma_{\mathrm{R}}$ & 0.813 & 7.914 & -0.051 & 0.32 & 9 & $\mathrm{H}, 3-\mathrm{Br}, 4-\mathrm{Br}, 3-\mathrm{Cl}, 4-\mathrm{Cl}, 4-\mathrm{F}, 4-\mathrm{OCH}_{3}, 3-\mathrm{NO}_{2}, 4-\mathrm{NO}_{2}$ \\
\hline & $F$ & 0.817 & 8.028 & -0.235 & 0.31 & 9 & $\mathrm{H}, 3-\mathrm{Br}, 4-\mathrm{Br}, 3-\mathrm{Cl}, 4-\mathrm{Cl}, 4-\mathrm{F}, 4-\mathrm{OCH}_{3}, 3-\mathrm{NO}_{2}, 4-\mathrm{NO}_{2}$ \\
\hline & $R$ & 0.804 & 7.932 & 0.055 & 0.32 & 9 & $\mathrm{H}, 3-\mathrm{Br}, 4-\mathrm{Br}, 3-\mathrm{Cl}, 4-\mathrm{Cl}, 4-\mathrm{F}, 4-\mathrm{OCH}_{3}, 3-\mathrm{NO}_{2}, 4-\mathrm{NO}_{2}$ \\
\hline \multirow[t]{6}{*}{$\delta \mathrm{C}=\mathrm{N}(\mathrm{ppm})$} & $\sigma$ & 0.813 & 146.57 & 1.388 & 3.62 & 9 & $\mathrm{H}, 3-\mathrm{Br}, 4-\mathrm{Br}, 3-\mathrm{Cl}, 4-\mathrm{Cl}, 4-\mathrm{F}, 4-\mathrm{OCH}_{3}, 3-\mathrm{NO}_{2}, 4-\mathrm{NO}_{2}$ \\
\hline & $\sigma^{+}$ & 0.817 & 146.68 & 1.237 & 3.60 & 9 & $\mathrm{H}, 3-\mathrm{Br}, 4-\mathrm{Br}, 3-\mathrm{Cl}, 4-\mathrm{Cl}, 4-\mathrm{F}, 4-\mathrm{OCH}_{3}, 3-\mathrm{NO}_{2}, 4-\mathrm{NO}_{2}$ \\
\hline & $\sigma_{\mathrm{I}}$ & 0.816 & 148.14 & -2.745 & 3.61 & 9 & $\mathrm{H}, 3-\mathrm{Br}, 4-\mathrm{Br}, 3-\mathrm{Cl}, 4-\mathrm{Cl}, 4-\mathrm{F}, 4-\mathrm{OCH}_{3}, 3-\mathrm{NO}_{2}, 4-\mathrm{NO}_{2}$ \\
\hline & $\sigma_{\mathrm{R}}$ & 0.808 & 147.14 & 1.322 & 3.64 & 9 & $\mathrm{H}, 3-\mathrm{Br}, 4-\mathrm{Br}, 3-\mathrm{Cl}, 4-\mathrm{Cl}, 4-\mathrm{F}, 4-\mathrm{OCH}_{3}, 3-\mathrm{NO}_{2}, 4-\mathrm{NO}_{2}$ \\
\hline & $F$ & 0.824 & 148.64 & -3.739 & 3.55 & 9 & $\mathrm{H}, 3-\mathrm{Br}, 4-\mathrm{Br}, 3-\mathrm{Cl}, 4-\mathrm{Cl}, 4-\mathrm{F}, 4-\mathrm{OCH}_{3}, 3-\mathrm{NO}_{2}, 4-\mathrm{NO}_{2}$ \\
\hline & $R$ & 0.817 & 147.38 & 2.254 & 3.60 & 9 & $\mathrm{H}, 3-\mathrm{Br}, 4-\mathrm{Br}, 3-\mathrm{Cl}, 4-\mathrm{Cl}, 4-\mathrm{F}, 4-\mathrm{OCH}_{3}, 3-\mathrm{NO}_{2}, 4-\mathrm{NO}_{2}$ \\
\hline
\end{tabular}

$\mathrm{r}=$ correlation coefficient, $\mathrm{I}=$ intercept, $\rho=$ slope, $\mathrm{s}=$ standard deviation, $\mathrm{n}=$ number of correlated derivatives 


\section{RESULTS AND DISSCUSION}

\subsection{UV-visible spectral correlations:}

The assigned UV absorption maximum $\lambda_{\max }(\mathrm{nm})$ values of all the substituted (E)-1-benzylidene-2-(4-chlorophenyl)hydrazines are presented in Table 1. These UV absorption maximum $\lambda_{\max }(\mathrm{nm})$ values are correlated with different Hammett substituent constants and $F$ and $R$ parameters using single and multi-linear regression analyses according to the approach of John Shorter [33]. Hammett equation employed, for the correlation analysis, involving the UV absorption maximum is shown in equation (1).

$$
\lambda=\rho \sigma+\lambda_{0}
$$

where $\lambda_{0}$ is the absorption maximum of the parent member of this series.

The results of statistical analysis [34-37] are shown in Table 2. From Table 2, it is evident that the UV absorption maximum $\lambda_{\max }(\mathrm{nm})$ values of all the substituted (E)-1-benzylidene-2-(4chlorophenyl)hydrazines have shown poor correlations $(\mathrm{r}<0.900)$ with Hammett substituent constants namely, $\sigma, \sigma^{+}, \sigma_{\mathrm{I}}, \sigma_{\mathrm{R}}$ and $F$ and $\mathrm{R}$ parameters. This is attributed to the weak polar, inductive, field and resonance effects of the substituents for predicting the reactivity on the UV absorption maximum $\lambda_{\max }(\mathrm{nm})$ values of all the $(E)$-1-benzylidene-2-(4-chlorophenyl)hydrazines through resonance as per the conjugative structure shown in Fig. 1.

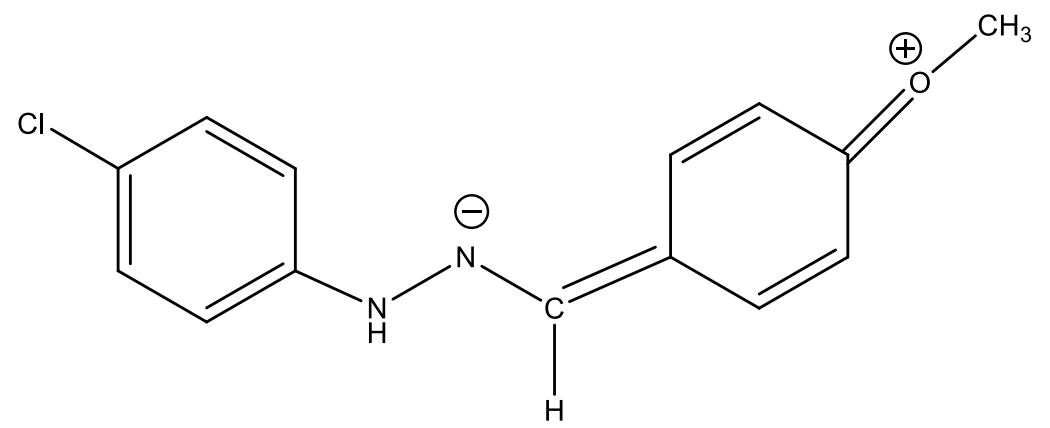

Fig. 1. The resonance-conjugative structure

All the correlations have shown negative $\rho$ values. This indicates the operation of reverse substituent effect with respect to $\mathrm{UV}$ absorption maximum $\lambda_{\max } \mathrm{C}=\mathrm{N}(\mathrm{nm})$ values in all the (E)-1-benzylidene-2-(4-chlorophenyl)hydrazine compounds. In this case all the single regression analyses have shown poor correlations with Hammett substituent constants namely, $\sigma, \sigma^{+}, \sigma_{\mathrm{I}}, \sigma_{\mathrm{R}}$ and $F$ and $R$ parameters, it is decided to go for multi-regression analysis. The multi-regression analysis of the UV absorption maximum $\lambda_{\max }(\mathrm{nm})$ values of all the substituted (E)-1-benzylidene-2-(4-chlorophenyl) hydrazine compounds with inductive, resonance and Swain-Lupton's [38] $F$ and $R$ parameters produce satisfactory correlations as shown in equations (2) and (3).

$$
\begin{gathered}
\lambda_{\max } \mathrm{C}=\mathrm{N}(\mathrm{nm})=350.21( \pm 4.69)-2.57( \pm 0.716) \sigma_{\mathrm{I}}-5.281( \pm 1.397) \sigma_{\mathrm{R}} \\
(R=0.929, \mathrm{n}=9, \mathrm{P}>90 \%) \\
\lambda_{\max } \mathrm{C}=\mathrm{N}(\mathrm{nm})=350.945( \pm 4.153)-4.476( \pm 1.007) F-4.771( \pm 1.791) R \\
(R=0.933, \mathrm{n}=9, \mathrm{P}>90 \%)
\end{gathered}
$$

\subsection{IR Spectral correlation}

The assigned infrared stretching frequency $v \mathrm{C}=\mathrm{N}\left(\mathrm{cm}^{-1}\right)$ values of all the substituted (E)-1-benzylidene-2-(4-chlorophenyl)hydrazines are presented in Table-1. These IR frequency $v \mathrm{C}=\mathrm{N}\left(\mathrm{cm}^{-1}\right)$ values are correlated with different Hammett substituent constants and $F$ and $R$ parameters using single and multi-linear regression analyses. The structure parameter correlation involving group frequencies, the employed Hammett equation is shown in equation (4).

$$
v=\rho \sigma+v_{0}
$$

Where $v_{0}$ is the frequency of the parent member of this series 
The results of the statistical analysis [34-37] are presented in Table 2, it is evident that the infrared stretching frequency $v \mathrm{C}=\mathrm{N}\left(\mathrm{cm}^{-1}\right)$ values of all the substituted $(E)-1$-benzylidene-2-(4chlorophenyl)hydrazines, except those with parent $(\mathrm{H})$ and $3-\mathrm{NO}_{2}$ substituents have shown satisfactory correlations with Hammett constants namely, $\sigma(r=0.905)$ and $\sigma^{+}(r=0.906)$. The infrared stretching frequency $v \mathrm{C}=\mathrm{N} \quad\left(\mathrm{cm}^{-1}\right)$ values of all the substituted (E)-1-benzylidene-2-(4-chlorophenyl)hydrazines, except those with 3- $\mathrm{NO}_{2}$ substituent have shown satisfactory correlations with Hammett constant $\sigma_{\mathrm{R}}(\mathrm{r}=0.906)$ and Swain-Lupton $R(\mathrm{r}=0.907)$ parameters. When these substituents that have been given exception are included in regression they reduce the correlations considerably. However the infrared stretching frequency $v C=N\left(\mathrm{~cm}^{-1}\right)$ values of all the substituted (E)-1-benzylidene-2-(4-chlorophenyl)hydrazines, have shown poor correlations $(\mathrm{r}<0.900)$ with the remaining Hammett constant $\sigma_{\mathrm{I}}$ and $F$ parameters. This is attributed to weak polar, inductive and field effect of the substituents to predict their electronic effects through resonance as per conjugative structure shown in Fig. 1.

Since some of the single regression analyses, have shown poor correlations with Hammett constant $\sigma_{\mathrm{I}}$ and $F$ parameters. It is decided to go for multi regression analysis. The multi regression analysis of the stretching frequency $v \mathrm{C}=\mathrm{N}\left(\mathrm{cm}^{-1}\right)$ values of all the substituted $(E)$-1-benzylidene-2(4-chlorophenyl)hydrazines with inductive, resonance and Swain-Lupton's [38] parameters produce satisfactory correlations as shown in equations (4) and (5).

$$
\begin{gathered}
v_{\mathrm{C}=\mathrm{N}}\left(\mathrm{cm}^{-1}\right)=1585.17( \pm 5.530)+1.757( \pm 0.380) \sigma_{\mathrm{I}}-22.817( \pm 4.895) \sigma_{\mathrm{R}} \\
(\mathrm{R}=0.968, \mathrm{n}=9, \mathrm{P}>95 \%) \\
v_{\mathrm{C}=\mathrm{N}}\left(\mathrm{cm}^{-1}\right)=1585.03( \pm 4.746)+0.708( \pm 0.021) F+19.777( \pm 3.761) R \\
(\mathrm{R}=0.972, \mathrm{n}=9, \mathrm{P}>95 \%)
\end{gathered}
$$

\subsection{NMR spectral correlation}

The assigned chemical shift values (ppm) of all the substituted (E)-1-benzylidene-2-(4chlorophenyl)hydrazines are presented in Table 1. These $\mathrm{CH}=\mathrm{N}(\delta \mathrm{ppm})$ chemical shift values are correlated with different Hammett substituent constants and $F$ and $R$ parameters using single and multi-linear regression analyses [34-37]. In this correlation, the structure-parameter equation employed is shown in equation (7).

$$
\delta=\rho \sigma+\delta_{0}
$$

where $\delta_{0}$ is the chemical shift of the corresponding parent compound.

\subsection{1. ${ }^{1} \mathrm{H}$ NMR spectral correlation}

The chemical shift $\mathrm{CH}=\mathrm{N}(\delta \mathrm{ppm})$ values of all the substituted (E)-1-benzylidene-2-(4chlorophenyl)hydrazines are presented in Table-1. The ${ }^{1} \mathrm{H}$ NMR spectral correlations of all the substituted (E)-1-benzylidene-2-(4-chlorophenyl)hydrazines are presented in Table 2.

From the results of the statistical analysis [34-37] the ${ }^{1} \mathrm{H}$ NMR chemical shift $\delta \mathrm{CH}=\mathrm{N}$ $(\mathrm{ppm})$ values of all the substituted $(E)$-1-benzylidene-2-(4-chlorophenyl)hydrazines have shown poor correlations $(\mathrm{r}<0.900)$ with different Hammett constants and Swain-Lupton's $F$ and $R$ parameters. The failure in correlation is due to the reason that has been stated earlier.

All the correlations with Hammett substituent constants namely $\sigma$, $\sigma+$ and $R$ parameters have shown positive $\rho$ values. It indicates the operation of normal substituent effect with respect to ${ }^{1} \mathrm{H}$ NMR spectral data of all the compounds.

All the single regression analyses have shown poor correlations. Hence, it is decided to go for multi-regression analysis. While seeking the multi-correlation collectively the Hammett constants namely $\sigma_{I}$ and $\sigma_{R}$ and $F$ and R parameters [38] have shown satisfactory correlation as shown in the equations (8) and (9).

$$
\begin{gathered}
\mathrm{CH}=\mathrm{N}\left(\delta_{p p m}\right)=7.925( \pm 0.320)-0.023( \pm 0.625) \sigma_{\mathrm{I}}-0.047( \pm 0.572) \sigma_{\mathrm{R}} \\
(R=0.904, \mathrm{n}=9, P>95 \%) \\
\mathrm{CH}=\mathrm{N}\left(\delta_{p p m}\right)=8.037( \pm 0.283)-0.233( \pm 0.546) F+0.048( \pm 0.463) R \\
(R=0.984, \mathrm{n}=9, P>95 \%)
\end{gathered}
$$

\subsection{2. ${ }^{13} \mathrm{C}$ NMR spectral correlation}

The results of the statistical analysis [34-37] are presented in Table-2. It is evident that the ${ }^{13} \mathrm{CNMR}$ chemical shift $\delta \mathrm{C}=\mathrm{N}(\mathrm{ppm})$ values of all the substituted $(E)-1$-benzylidene-2-(4- 
chlorophenyl)hydrazines have shown poor correlations $(\mathrm{r}<0.900)$ with different Hammett constants and Swain-Lupton's $F$ and $R$ parameters. The failure in correlation is due to the reason that has been stated earlier with resonance conjugative structure as shown in Fig. 2. The Hammett constants $\sigma, \sigma+, \sigma_{\mathrm{R}}$ and $R$ parameters have shown positive $\rho$ values. This shows that the normal substituent effect operates in all systems. While seeking the multi-correlation, collectively with inductive, resonance and field effects [38] satisfactory correlation as shown in equations (10) and (11).

$$
\begin{gathered}
\mathrm{C}=\mathrm{N}\left(\delta_{\mathrm{ppm}}\right)=148.60( \pm 3.562)-3.174( \pm 1.957) \sigma_{\mathrm{I}}+1.918( \pm 0.437) \sigma_{\mathrm{R}} \\
(R=0.973, \mathrm{n}=9, \mathrm{P}>95 \%) \\
\mathrm{C}=\mathrm{N}\left(\delta_{\mathrm{ppm}}\right)=149.01( \pm 3.125)-3,646( \pm 1.026) \mathrm{F}+2.139( \pm 0.711) \mathrm{R} \\
(R=0.929, \mathrm{n}=9, \mathrm{P}>95 \%)
\end{gathered}
$$

\section{Antimicrobial activities of (E)-1-benzylidene-2-(4-chlorophenyl)hydrazines \\ 4.1. Antibacterial sensitivity assay}

The antibacterial activities of all the $(E)$-1-benzylidene-2-(4-chlorophenyl)hydrazines was done following the disc diffusion technique [39]. All the (E)-1-benzylidene-2-(4chlorophenyl)hydrazine compounds were screened for their in antibacterial activity against $B$. subtilis, M. luteus, S. aureus, E. coli and $P$. aeruginosa at a concentration $250 \mu \mathrm{g} / \mathrm{mL}$ with ciprofloxacin as the standard drug. The antibacterial activity of all the (E)-1-benzylidene-2-(4chlorophenyl)hydrazines is shown in Fig. 2 (Plates 1-10). The measured zone of inhibition values are given in Table 3 and the corresponding clustered column chart is shown in Fig. 3. Analysis of the zone of inhibition $(\mathrm{mm})$ values reveals that the $(E)$-1-benzylidene-2-(4-chlorophenyl)hydrazines with 3-Cl, 4-F, 4-OCH 3 and 3- $\mathrm{NO}_{2}$ substituents have shown good antibacterial against $B$. subtilis, $M$. luteus species. The (E)-1-benzylidene-2-(4-chlorophenyl)hydrazines with parent $(\mathrm{H}), 3-\mathrm{Br}, 4-\mathrm{Br}$, 4-Cl and 4- $\mathrm{NO}_{2}$ substituents showed moderate antibacterial activity against $B$. subtilis, M. luteus species. The $(E)$-1-benzylidene-2-(4-chlorophenyl)hydrazines with 4- $\mathrm{NO}_{2}$ substituent have shown excellent activity against $M$. luteus species. The $(E)$-1-benzylidene-2-(4-chlorophenyl)hydrazines with 3-Cl, 4-Cl, 4-F, 4-OCH $3,3-\mathrm{NO}_{2}$ and 4- $\mathrm{NO}_{2}$ substituents have shown good antibacterial activity against $S$. aureus species. The remaining three (E)-1-benzylidene-2-(4-chlorophenyl)hydrazines with parent $(\mathrm{H}), 3-\mathrm{Br}$ and $4-\mathrm{Br}$ substituents has shown moderate antibacterial activity against $S$. aureus species

The eight $(E)$-1-benzylidene-2-(4-chlorophenyl)hydrazines with parent $(\mathrm{H}), 4-\mathrm{Br}, 3-\mathrm{Cl}, 4-\mathrm{Cl}$, 4-F, 4- $-\mathrm{OCH}_{3}, 3-\mathrm{NO}_{2}$ and 4- $\mathrm{NO}_{2}$ substituents has shown good antibacterial activity against $E$. coli species. The remaining one $(E)$-1-benzylidene-2-(4-chlorophenyl)hydrazines with 3-Br substituent have shown moderate antibacterial activity against $E$. coli species. The four $(E)-1-$ benzylidene-2-(4chlorophenyl)hydrazines with 3-Cl, 4-Cl, 4-F and 4- $\mathrm{NO}_{2}$ substituents have shown good antibacterial activity $S$. aureus species. The three $(E)$-1-benzylidene-2-(4-chlorophenyl)hydrazines with parent (H), 3-Br and 3- $\mathrm{NO}_{2}$ substituents has shown moderate antibacterial activity $S$. aureus species. The remaining two $(E)$-1-benzylidene-2-(4-chlorophenyl)hydrazines compounds with 4- $\mathrm{Br}$ and 4-OCH substituents has shown poor antibacterial activity against $S$. aureus species. 


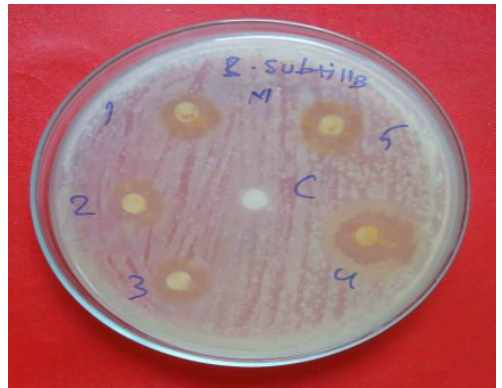

Plate-1

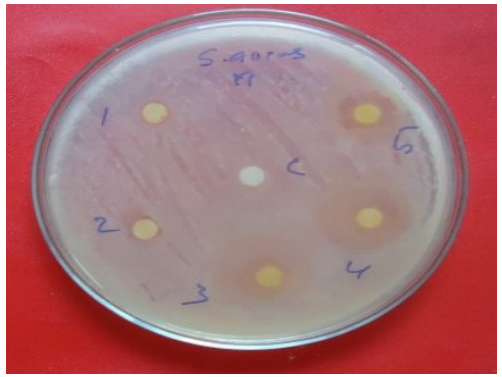

Plate-3

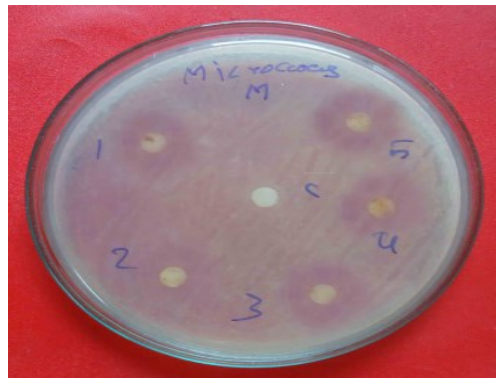

Plate-5

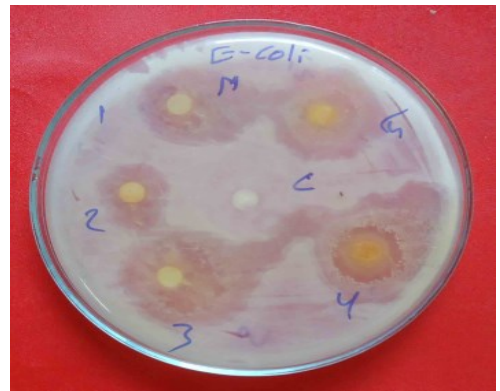

Plate-7

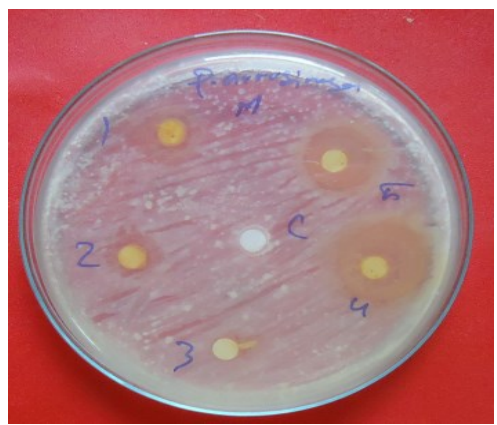

plate-9

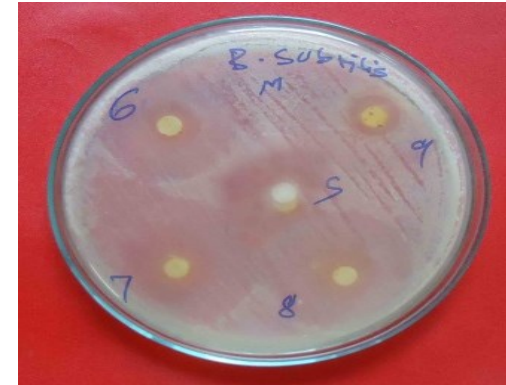

Plate-2

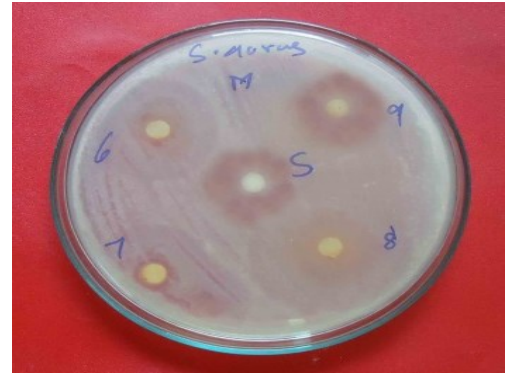

Plate-4

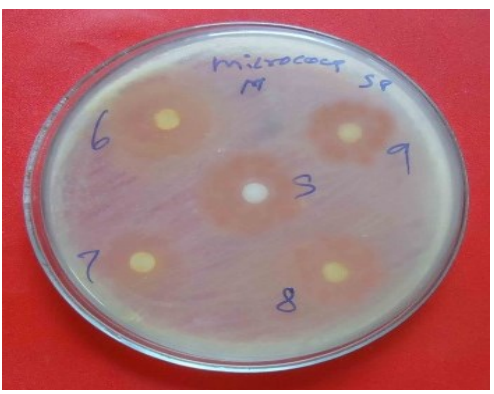

Plate-6

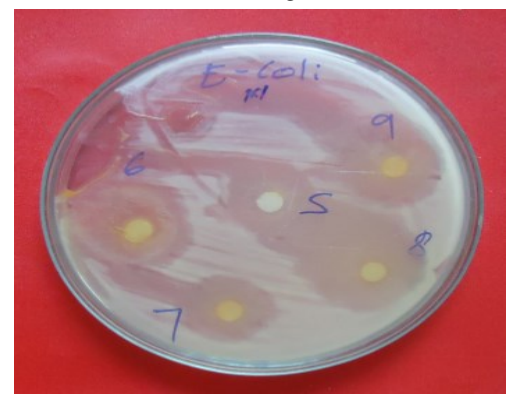

Plate- 8

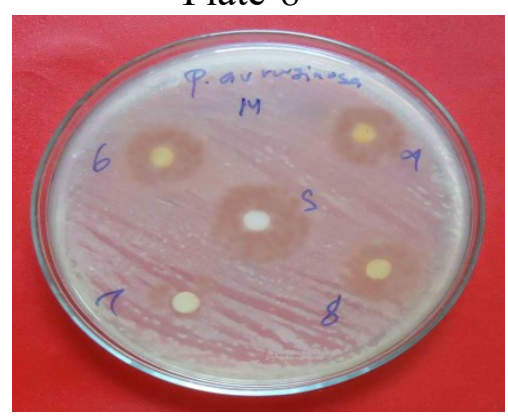

plate-10

Fig. 2. Antibacterial activity of substituted (E)-1-benzylidene-2-(4-chlorophenyl)hydrazines (petri-plates) 
Table 3. The zone of inhibition $(\mathrm{mm})$ values of antibacterial activity of $(E)-1$-benzylidene-2-(4chlorophenyl)hydrazines

\begin{tabular}{|c|c|c|c|c|c|c|}
\hline \multirow{2}{*}{ S.No. } & \multirow{2}{*}{} & Substituents & \multicolumn{5}{|c|}{ Zone of inhibition(mm) } \\
\cline { 3 - 7 } & \multicolumn{4}{|c|}{ Gram positive Bacteria } & \multicolumn{2}{c|}{ Gram negative Bacteria } \\
\cline { 3 - 7 } & B.subtilis & M.luteus & S.aureus & E.coli & P.aeruginosa \\
\hline 2 & $3-\mathrm{Br}$ & 6 & 0 & 8 & 10 & 6 \\
\hline 3 & $4-\mathrm{Br}$ & 6 & 8 & 9 & 8 & 6 \\
\hline 4 & $3-\mathrm{Cl}$ & 12 & 11 & 10 & 15 & 0 \\
\hline 5 & $4-\mathrm{Cl}$ & 9 & 9 & 10 & 12 & 14 \\
\hline 6 & $4-\mathrm{F}$ & 13 & 10 & 12 & 13 & 10 \\
\hline 7 & $4-\mathrm{OCH}_{3}$ & 16 & 13 & 10 & 10 & 0 \\
\hline 8 & $3-\mathrm{NO}_{2}$ & 14 & 12 & 10 & 16 & 9 \\
\hline 9 & $4-\mathrm{NO}_{2}$ & 8 & 16 & 12 & 15 & 10 \\
\hline Standard & Ciprofloxacin & 16 & 15 & 16 & 16 & 15 \\
\hline Control & DMSO & 0 & 0 & 0 & 0 & 0 \\
\hline
\end{tabular}

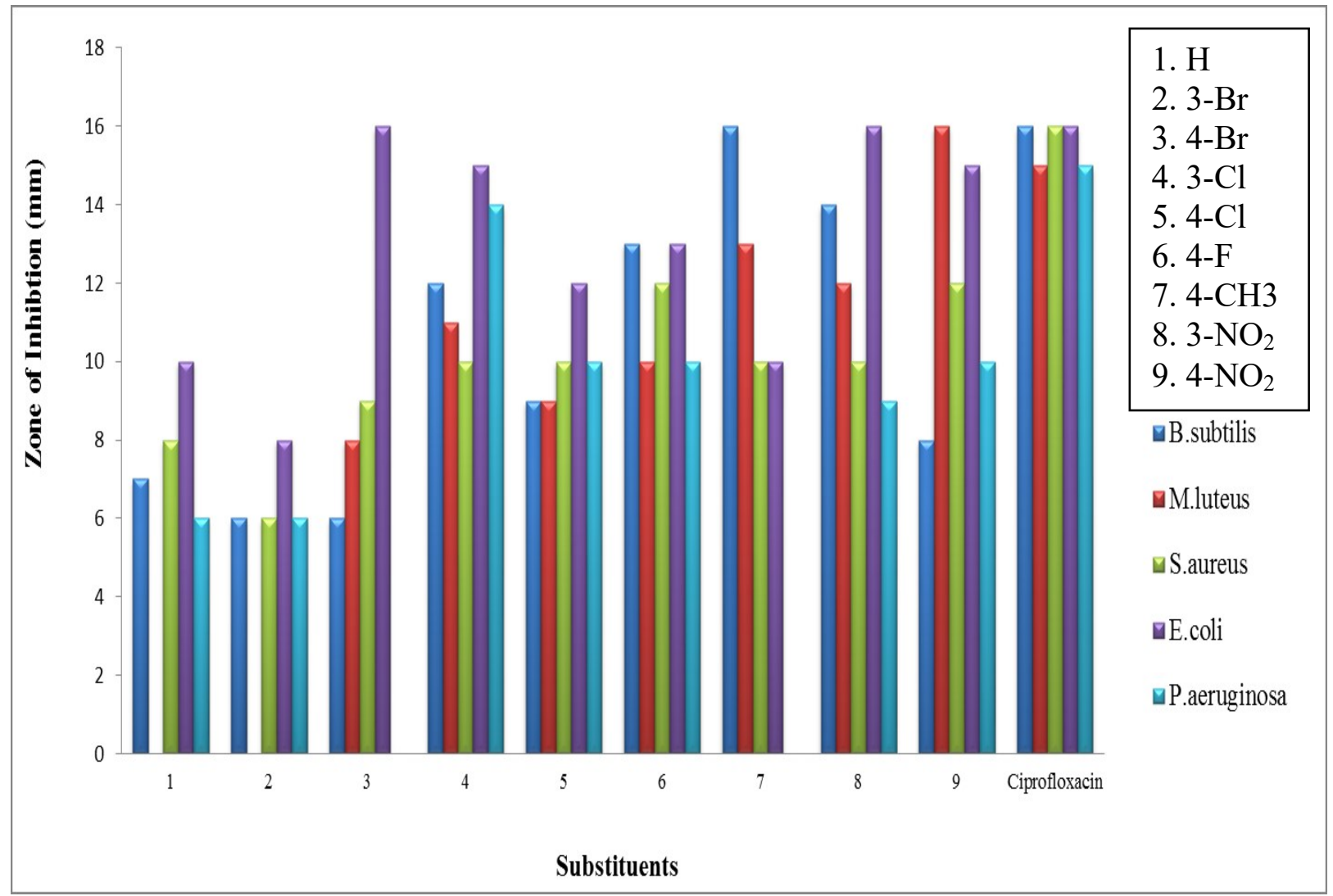

Fig. 3. Antibacterial activity of substituted (E)-1-benzylidene-2-(4-chlorophenyl)hydrazines (clustered column chart) 


\subsection{Antifungal activity}

Antifungal assay has been performed using Kirby-Bauer [39] disc diffusion technique. The antifungal activities of all the substituted (E)-1-benzylidene-2-(4-chlorophenyl)hydrazines have been studied and are shown in Fig. 4 for Plates (1-4). The zone of inhibition values of the antifungal activities is given in Table 4. The clustered column chart was shown in Fig. 5 and it reveals that the $(E)$-1-benzylidene-2-(4-chlorophenyl)hydrazine compounds with Parent $(\mathrm{H}), 3-\mathrm{Br}$, 4- $\mathrm{Br}, 4-\mathrm{Cl}$ and 4-F substituents have shown moderate antifungal activity against $A$. niger species. The (E)-1-benzylidene-2-(4-chlorophenyl)hydrazines having substituents $4-\mathrm{OCH}_{3}$ and $4-\mathrm{NO}_{2}$ have shown good antifungal activity against $A$. niger alone. The (E)-1-benzylidene-2-(4chlorophenyl)hydrazines with 3-NO $\mathrm{NO}_{2}$ substituent have shown excellent antifungal activity against $A$. niger species. The (E)-1-benzylidene-2-(4-chlorophenyl)hydrazines with 3-Br, 4- $\mathrm{Br}$ and 3-Cl substituents have shown improve antifungal activity against Mucor Species. The (E)-1-benzylidene2-(4-chlorophenyl)hydrazines with 4-Cl, 4-F, 3- $\mathrm{NO}_{2}$ and 4- $\mathrm{NO}_{2}$ substituents have shown good antifungal activity against Mucor Species. The (E)-1-benzylidene-2-(4-chlorophenyl)hydrazines with $4-\mathrm{OCH}_{3}$ substituent have shown excellent antifungal activity against Mucor Species. The (E)1-benzylidene-2-(4-chlorophenyl)hydrazines with Parent $(\mathrm{H}), 3-\mathrm{Br}, 3-\mathrm{Cl}$, 4-F, 3- $\mathrm{NO}_{2}$ and 4- $\mathrm{NO}_{2}$ substituents have shown improve antifungal activity against T.viride Species. The (E)-1benzylidene-2-(4-chlorophenyl)hydrazines with $4-\mathrm{OCH}_{3}$ substituent have shown good antifungal activity against $T$.viride Species.

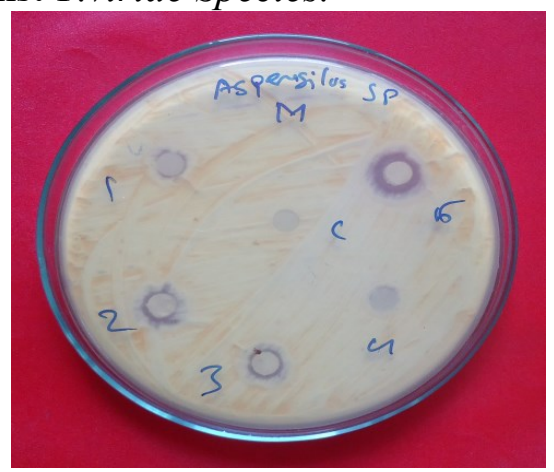

Plate-1

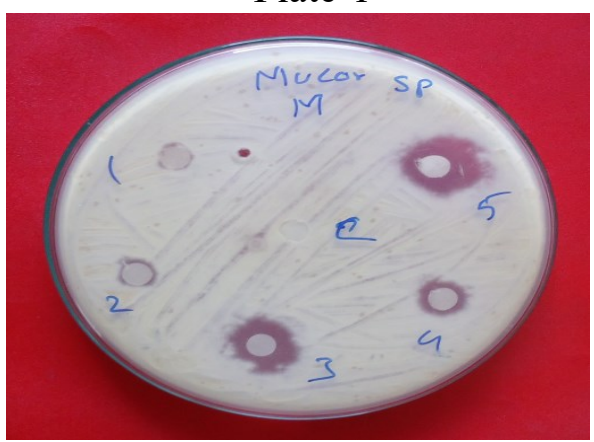

Plate-3

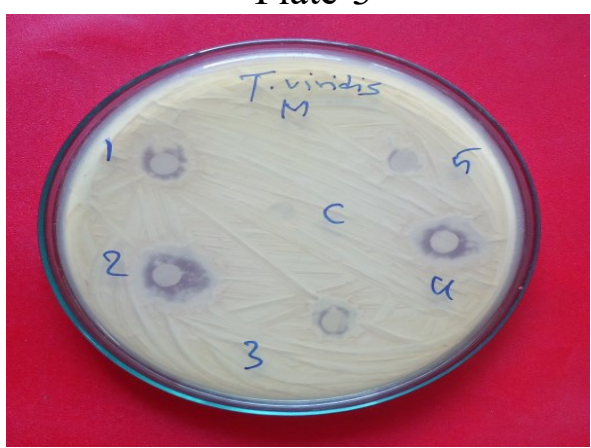

Plate-5

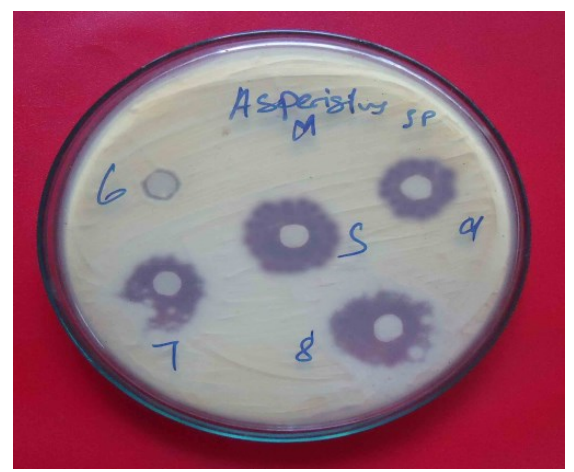

Plate-2

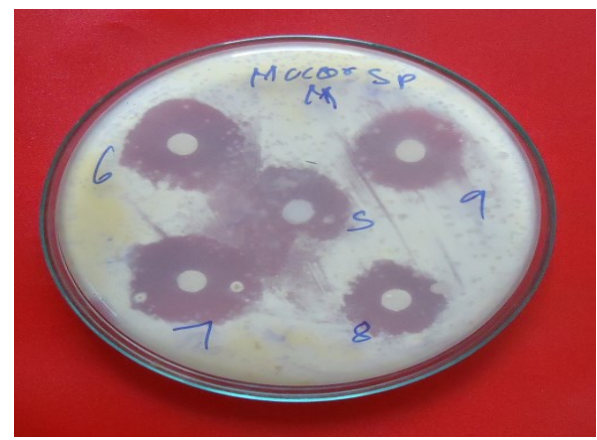

Plate-4

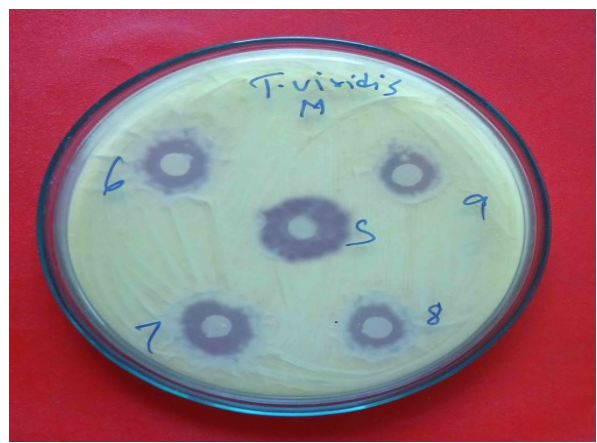

Plate-6

Fig. 4. Antifungal activity of substituted (E)-1-benzylidene-2-(4-chlorophenyl)hydrazines (petriplates) 
Table 4. The zone of inhibition ( $\mathrm{mm})$ values of antifungal activities of $(E)$-1-benzylidene-2(4-chlorophenyl)hydrazines

\begin{tabular}{|c|c|c|c|c|}
\hline \multirow{2}{*}{ S.No } & \multirow{2}{*}{ Compounds } & \multicolumn{3}{|c|}{ Zone of Inhibition (mm) } \\
\cline { 3 - 5 } & $\mathrm{H}$ & A.niger & M.species & T.viride \\
\hline 1 & $3-\mathrm{Br}$ & 6 & 0 & 6 \\
\hline 2 & $4-\mathrm{Br}$ & 6 & 6 & 7 \\
\hline 3 & $3-\mathrm{Cl}$ & 0 & 7 & 0 \\
\hline 4 & $4-\mathrm{Cl}$ & 8 & 10 & 6 \\
\hline 5 & $4-\mathrm{F}$ & 6 & 18 & 8 \\
\hline 6 & $4-\mathrm{OCH}$ & 13 & 24 & 10 \\
\hline 7 & $3-\mathrm{NO}_{2}$ & 21 & 19 & 8 \\
\hline 8 & $4-\mathrm{NO}_{2}$ & 14 & 20 & 18 \\
\hline 9 & Micnazole & 20 & 0 & 0 \\
\hline Standard & DMSO & 0 & & 0 \\
\hline Control & & & & \\
\hline
\end{tabular}

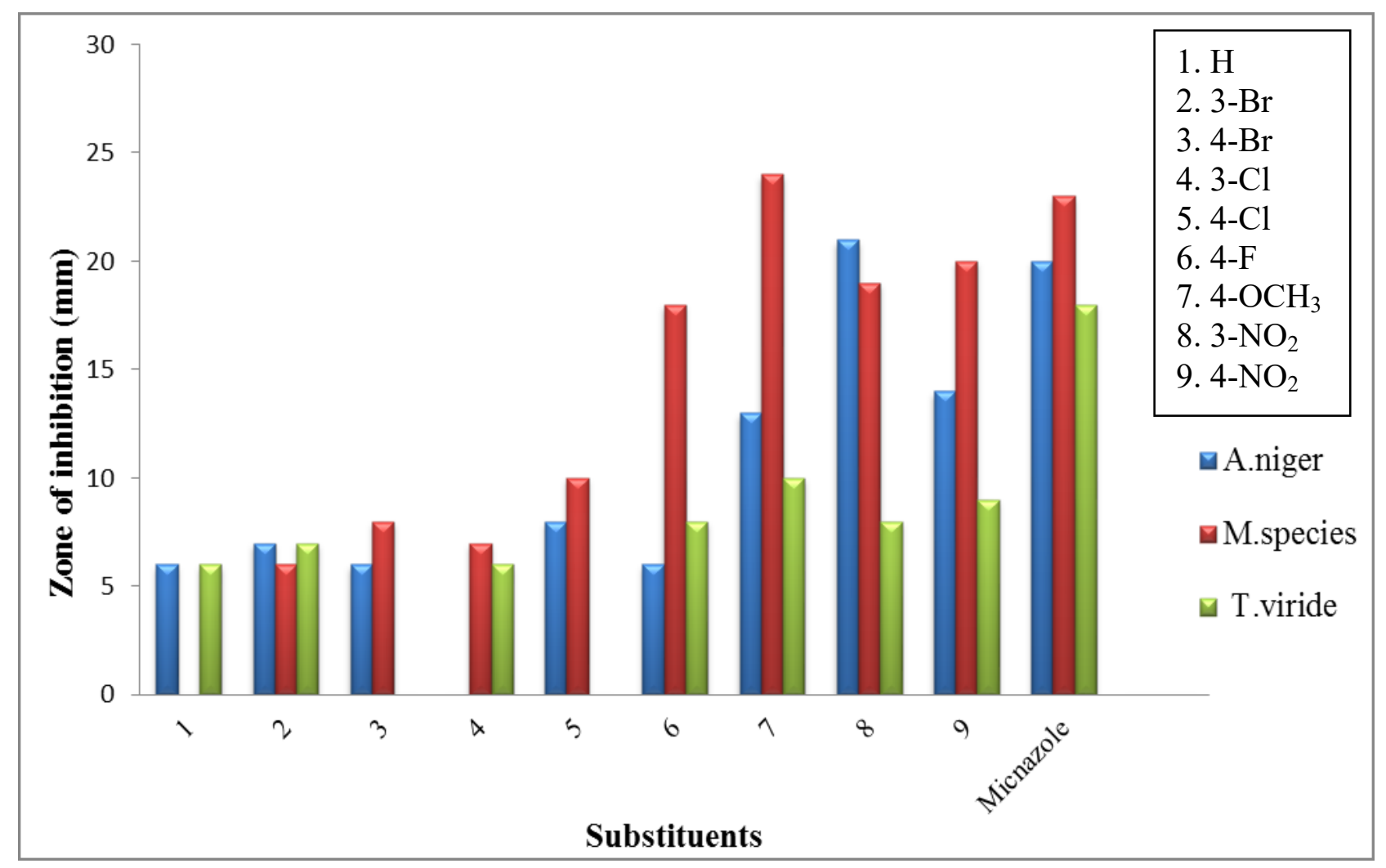

Fig. 5. Antifungal activity of substituted (E)-1-benzylidene-2-(4-chlorophenyl)hydrazines (clustered column chart) 


\section{CONCLUSION}

A series of nine number of (E)-1-benzylidene-2-(4-chlorophenyl)hydrazines have been synthesized by condensation reaction of various meta- and para- substituted benzaldehydes containing either electron-releasing or electron-withdrawing groups, 4-chlorophenylhydrazine with acetic acid acid. The yield of the product is more than $80 \%$. The synthesized substituted (E)-1-benzylidene-2-(4-chlorophenyl)hydrazines are characterized by their physical constants and the UV, IR, and NMR spectral data. The UV, IR, and NMR spectral data of the substituted (E)-1-benzylidene-2-(4-chlorophenyl)hydrazines have been correlated with Hammett constants $\sigma, \sigma^{+}, \sigma_{\mathrm{I}}, \sigma_{\mathrm{R}}$ and swain-Lupton's $F$ and $R$ parameters using single and multi-regression analyses. The single parameter correlation with few Hammett constants and $F$ and $R$ parameters gave satisfactory correlation whereas all multiple correlations gave satisfactory correlation coefficients with Resonance, Field and Swain-Lupton's parameters. The Antimicrobial activities of all synthesized (E)-1-benzylidene-2-(4-chlorophenyl)hydrazines have been studied using Bauer-Kirby method.

\section{Acknowledgement}

The authors thank to DST NMR Facility Unit, Department of Chemistry, Annamalai University, Annamalainagar-608002 for recording NMR spectra of all the hydrazone compounds.

\section{References}

[1] J. P. Cornelissen, J. H. Van Diemen, L. R. Groeneveld, J. G. Haasnoot A. L. Spek, J. Reedijk, Inorg. Chem, 31(2) (1992)198.

[2] M. B. Smith, M. Jerry, March's Advanced Organic Chemistry, Reactions, Mechanisms, and Structure, John Wiley \& Sons,Milton, Australia, 6th edition, 2007.

[3] R. Lazny, A. Nodzewska, Chem. Rev, 110 (3) (2010) 1386-1434.

[4] S. N. P. Belskaya, W. Dehaen, V. A. Bakuleva, Arkivoc, 2010 (1) (2010) 275-332.

[5] R. Brehme, D. Enders, R. Fernandez, J. M. Lassaletta, Eur. J. Org. Chem, 2007 (34) (2007) 5629-5660.

[6] S. Berdinskii, Chem. Hetero. Comp, 15 (2) (1979) 238-246.

[7] P. A. S. Smith, Benjamin Cummings, Reading, Mass, USA, 1983.

[8] V. Polshettiwar, R. S. Varma, Tetrahedron Lett, 48 (32) (2007) 5649-5652.

[9] S. Rollas, S. G Kucukguzel, Molecule, 12 (2007) 1910-1939.

[10] S. Rollas, N. Gulerman, H. Edeniz, Farmaco, 57 (2002) 171-174.

[11] Imramovsky, S. Polanc, J. Vinsova, M. Kocevar, J. Jampitek, Z. Reckova, J. A. Kaustova, Bio. org. Med. Chem, 15 (2007) 2551-2559.

[12] J. R. Dimmock, S. C. Vasishtha, J. P. Stables, Eur. J. Med. Chem. 35 (2000) 241248.

[13] P. C. Lima, L. M. Lima, K. C. Silva, P. H. Leda, A. L. P. Miranda, C. A. M. Fraga, E. J. Barreiro, Eur. J. Med. Chem, 35 (2000) 879-886.

[14] U. Salgin-Goksen, N. Gokham-Keleci, O. Gostal, Y. Koysal, E. Kilici, S. Isik, G. Aktay, M. Ozalp, Bioorg. Med. Chem, 15 (17) (2007) 5738-5751.

[15] G. A. Silva, L. M. M. Costa, F. C. F. Brito, A. L. P. Miranda, E. J. Barreiro, C. A. M. Fraga, Bioorg. Med. Chem. 12 (2004) 3149-3158.

[16] Bijev, Lett. Drug. Descrip. Discovery, 3 (2006) 506-512. 
[17] M. T. Abdel-Aal, W. A. El-sayed, E. H. El-ashry, Arch. Pharm. Chem. Life Sci. 339 (2006) 656-663.

[18] S. A. M. El-Hawash, W. A. E. Abdel, M. A. El-Dewellawy, Arch. Pharm. Chem. Life. Sci. 339 (2006)14-23.

[19] Walcourt, M. Loyevsky, D. B. Lovejoy, V. R. Gordeuk, D. R. Richardson, Int. J. Biochem. Cell. Biol, 36 (2004) 401-407.

[20] N. Belkheiri, B. Bouguerne, F. Bedos-Belval, H. Duran, C. Bernis, R. Salvayre, A. NègreSalvayre, M. Baltas, Eur. J. Med. Chem. 45 (2010) 3019-3026.

[21] D. Duarte, E. J. Barreiro, C. A. M. Fraga, Mini-Rev. Med. Chem, 7 (11) (2007) 1108-1119.

[22] M. E. Caputto, L. E. Fabian, D. Benitez, A.Merlino, N.Rios,H.Cerectto, Bioorg. Med. Chem, 19 (22) (2011) 6818-6826.

[23] M. A. S. Aslam, S. U. Mahmood, M. Shahid, A. Saeed, J. Iqbal, Eur. J. Med. Chem, 46 (11) (2011) 5473-5479.

[24] O. I. El-Sabbagh, M. A. Shabaan, H. H. Kadry, and E. S. Al-Din, Eur. J. Med. Chem, 45 (11) (2010) 5390-5396.

[25] M. Catto, R. Aliano, A. Carotti, S. Cellamare, F. Palluotto, R. Purgatorio, A. D. Stradis, F. Campagna, Eur. J. Med. Chem. 45 (2010) 1359-1366.

[26] Kajal, S. Bala, N. Sharma, S. Kamboj, V. Saini, Int. J. Med. Chem, 4 (2014) 1153-1165.

[27] M. Wu, P. D. Senter, Nat. Biotechnol, 23 (9) (2005) 1137-1146.

[28] P. F. Gordon, P. Gregory, Organic chemistry in colour, Springer, New York, 1987.

[29] L. M. Hayden, W. K. Kim, A. P. Chafin, G. A. Lindsay, Macromolecules, 34 (2001) 1493-1495.

[30] H. Ahmad Shad, M. Nawaz Tahir, M. Ilyas Tariq, M. Sarfrazc, S. Ahmad, Acta Cryst, 66 (2010) 1955.

[31] J. Rong Hu, W. Jia Zhang, D. Gui Zheng, Tetrahedron, 69 (2013) 9865-9869.

[32] V. Polshettiwar, R. S. Varma, Tetrahedron Lett, 48 (2007) 5649-5652

[33] J. Shorter, Correlation analysis in Chemistry: an introduction to linear free energy relationships, Clarendon press, London, 1973.

[34] M. Rajarajan, R. Senbagam, R. Vijayakumar, V. Manikandan, S. Balaji, G. Vanangamudi, G. Thirunarayanan, World Scientific News, 3 (2015) 155-171.

[35] R. Vijayakumar, M. Rajarajan, S. Balaji, V. Manikandan, R. Senbagam G. Vanangamudi G. Thirunarayanan, World Scientific News, 3 (2015) 81-98.

[36] R. Senbagam, M. Rajarajan, R. Vijayakumar, V. Manikandan, S. Balaji, G. Vanangamudi, G. Thirunarayan, Int. Let. Chem. Phy. Ast, 53 (2015) 154-164.

[37] G. Thirunarayanan, S. Pazhamalai, K. G. Sekar, Int. Let. Chem. Phy. Ast, 8 (2014) 38-46

[38] G. Swain, E. C. Lupton, J. Am. Chem. Soc, 90 (1968) 4328-4337.

[39] W. Bauer, W. M. M. Kirby, J. C. Sherris M. Truck, Am. J. Clinical Pathology, 45 (1966) 493498. 